\title{
Validation of Spiked Postmortem Blood Samples from Cornea Donors on the Abbott ARCHITECT and m2000 Systems for Viral Infections
}

\author{
Ingo Schmack ${ }^{\text {a, b }}$ Seda Ballikaya ${ }^{a}$ Brigitte Erber ${ }^{a}$ Irina Voehringer ${ }^{a}$ \\ Ulrich Burkhardt ${ }^{c, d}$ Gerd U. Auffarth ${ }^{a}$ Paul Schnitzler ${ }^{d}$ \\ ${ }^{a}$ Department of Ophthalmology, Heidelberg University, Heidelberg, Germany; ${ }^{\mathrm{b}}$ Department of Ophthalmology, \\ Goethe University Frankfurt, Frankfurt am Main, Germany; ${ }^{C}$ Klinikum Ludwigshafen, Ludwigshafen, Germany; \\ ${ }^{\mathrm{d} C e n t e r}$ for Infectious Diseases, Virology, Heidelberg University Hospital, Heidelberg, Germany
}

\section{Keywords \\ Cornea donor · Postmortem blood samples · Serologic screening $\cdot$ Hepatitis B virus · Hepatitis $C$ virus · Human immunodeficiency virus}

\begin{abstract}
Background: Transplantation of human corneal tissue is associated with the potential risk of transmittance of viral infections. In accordance with European directives and federal laws, in Germany each tissue donor has to be tested for infectious diseases such as hepatitis $B$ and $C$ virus (HBV and HCV) and human immunodeficiency virus (HIV) infection. However, most of the currently available CE-marked serologic and nucleic acid screening systems are only validated for antemortem blood. Methods: Twenty related and paired anteand postmortem blood samples from cornea donors were obtained and subsequently analyzed for hepatitis B surface antigen (HBsAg), hepatitis B antibody (anti-HBc), anti-HCV, HCV RNA, anti-HIV-1/2, and HIV p24 Ag using Abbott test systems. The sera were also spiked with reference materials in concentrations giving low and high positivity for HBV, HCV, and HIV markers. Results: The spiked ante- and postmortem sera from related donors showed similar results for
\end{abstract}

HBsAg, anti-HBc, anti-HCV, HCV RNA, anti-HIV, and HIV p24 $\mathrm{Ag}$, indicating a high stability of viral markers in cadaveric specimens. Three cornea donors had a medical history of $\mathrm{HBV}$ infection and revealed anti-HBc at similar levels in the ante- and postmortem sera. In addition, there was a single postmortem sample demonstrating a weak signal of antiHIV-1 and HIV-1 p24 Ag. False-positive or false-negative results were not detected. The results obtained with the Abbott ARCHITECT analyzer and Abbott RealTime HCV PCR showed no significant differences. Conclusion: The analyzed screening assays are suitable for the detection of infectious markers of HBV, HCV, and HIV at similar levels in spiked anteand postmortem sera from cornea donors.

C 2019 S. Karger AG, Basel

\section{Introduction}

Corneal grafting, first carried out by Eduard Zirm in 1906, still represents the most common and successful transplantation of allogenic tissues in humans $[1,2]$. Worldwide, about 100,000 corneal transplantations are performed annually. Over the last decade, various European and national directives and regulations have been 
passed to harmonize the process of donor acquisition, as well as the testing, preparation, storage, and distribution of corneal tissue [3-7]. In particular, screening of tissue donors for blood-derived viral infections such as hepatitis $B$ virus (HBV), hepatitis $\mathrm{C}$ virus (HCV), and human immunodeficiency virus (HIV) became mandatory in the context of the release of donor corneas for transplantation [8-11].

Despite continuous improvement and standardization of serologic and nuclear amplification test (NAT) systems, there is still a potential risk for transmittance of infectious diseases during tissue transplantation. Overall, the incidence of transmittance of $\mathrm{HBV}, \mathrm{HCV}$, or human immunodeficiency virus (HIV) is statistically significantly lower among tissue donors than in the untested normal population [12]. However, in comparison to first-time blood donors, the risk of infection with HBV, HCV, or HIV is still higher among tissue donors. This is in part related to the fact that blood testing of cornea donors can also be performed on postmortem blood samples, which bear the potential risk of false-negative or false-positive results due to postmortem changes such as hemolysis, autolysis, or protein degradation $[3,4]$. Currently available CE-marked tests are mainly validated for antemortem blood testing only. To minimize these limitations, analysis of postmortem sera is only allowed in situations where antemortem samples are not available and postmortem blood samples are obtained within $24 \mathrm{~h}$ of death [3].

The German Federal Institute for Vaccines and Biomedicines (Paul Ehrlich Institute [PEI]) is responsible for tissue preparations and requires cornea banks to validate their test systems by spiking when using cadaveric blood. Currently, only postmortem samples from virus-infected cornea donors had been evaluated [13]. In addition, screening for anti-HCV antibodies and HCV RNA in potential cornea donors showed a high rate of indeterminate results when validating postmortem serum samples [14]. Two studies evaluating unspiked paired ante- and postmortem blood samples showed that some of the analyzed samples were discordant due to the use of unvalidated test systems [15, 16]. Kalus et al. [17] obtained 10 samples of ante- and postmortem sera from cornea donors and tested them for anti-Treponema pallidum antibodies on a Siemens BEP-III system.

To address this issue, ante- and postmortem blood samples from related cornea donors were spiked with infectious disease markers of HBV, HCV, and HIV in accordance with PEI recommendations and validated with Abbott test systems. In addition, PCR testing for HCV of HCV RNA-spiked samples was performed. The introduction of validated tests suitable for postmortem serum would significantly expand the availability of corneal tissue and reduce the waiting period for cornea recipients.

\section{Materials and Methods}

\section{Blood Sampling}

Related and paired ante- and postmortem blood samples were prospectively collected from 20 cornea donors by the cornea bank of Heidelberg University Hospital, Germany. Antemortem sera were provided by the Institute of Laboratory Medicine of Heidelberg University Hospital. Postmortem blood sampling (at least 6 $\mathrm{mL}$ of whole blood) was performed within $24 \mathrm{~h}$ of death in a standardized fashion from the femoral or subclavian vein; all procedures were performed in accordance with international guidelines [3]. All samples were immediately transferred to the Center for Infectious Diseases, Virology, at Heidelberg University Hospital for further analysis.

The ante- and postmortem samples were checked for hemolysis, and none of the analyzed samples was hemolytic. The blood samples were centrifuged within $1 \mathrm{~h}$ after blood withdrawal and serum was fractionated in three portions of about $2 \mathrm{~mL}$ of serum each. The ante- and postmortem serum samples were either tested the same day or kept frozen at $-80 \pm 5^{\circ} \mathrm{C}$ for up to 2 weeks for further analysis. Prior to testing, frozen serum samples were transferred to a refrigerator $\left(2-8^{\circ} \mathrm{C}\right)$ in order to thaw them for $12-16 \mathrm{~h}$.

\section{Spiking of Ante- and Postmortem Serum Samples}

The following PEI standards and World Health Organization (WHO) reference materials were used for the spiking experiments: hepatitis B surface antigen (HbsAg), subtype Ad, $100 \mathrm{U} / \mathrm{mL}$ (PEI); hepatitis B antibody (anti-HBc) IgG, $100 \mathrm{U} / \mathrm{mL}$ (PEI); hepatitis C antibody (anti-HCV) IgG reference serum (PEI); HCV RNA reference preparation, 40,000 IU/ampoule (PEI); HIV-1 antibody (anti-HIV-1) IgG reference serum IV (PEI); and HIV-1 p24 antigen (WHO).

In order to detect potential inhibitors in the samples that might interfere with the assays, the ante- and postmortem samples were spiked with markers of HBV, HCV, and HIV infection. The first aliquot of each ante- and postmortem sample was tested unspiked and served as a negative control. The second and third aliquots were spiked according to PEI recommendations with viral antigens, antibodies or HCV RNA, respectively. The sample/cutoff (S/ $\mathrm{CO}$ ) ratios or viral load for HCV RNA were compared between sets of related and paired ante- and postmortem blood samples of the same donor.

Spiking itself was performed using a defined quantity of infectious disease markers based on PEI recommendations. In detail, freeze-dried standards (anti-HCV IgG, HCV RNA, and antiHIV-1) were dissolved in a $0.9 \%$ isotonic sodium chloride solution (Braun, Melsungen, Germany). The required pre-dilutions of the standards were obtained using serologically negatively tested human serum of blood donors. The final concentrations/dilutions of the viral antigens/antibodies or RNA were as follows: $0.05 \mathrm{U}$ HBsAg, 2 U anti-HBc, 1:150 anti-HCV, 40 IU/mL HCV RNA, 1: 100,000 anti-HIV, and $2.5 \mathrm{U} / \mathrm{mL}$ HIV p24 antigen.

\section{Analysis of Ante- and Postmortem Blood Samples}

The following test kits, not approved for cadaveric serum samples, were used for validation: Abbott HBsAg Qualitative II chemoluminescence microparticle immunoassay (CMIA); Abbott anti-HBc II (CMIA); Abbott anti-HCV (CMIA); Abbott RealTime HCV (PCR); and Abbott HIV Ag/Ab Combo (CMIA). The analyses of HBsAg, anti-HBc, anti-HCV, anti-HIV, and HIV p24 antigen were performed on the ARCHITECT i2000 system (Abbott Diagnostics, Wiesbaden, Germany). All test kits for viral antibody/ antigen detection were CMIAs from Abbott Diagnostics. Detection of HBV DNA, HCV RNA, and HIV RNA was performed with an Abbott m2000rt cycler. In all PCR assays, an internal control 
Table 1. Donor characteristics

\begin{tabular}{llll}
\hline Subject No. & Age, years & Sex & PM time, h \\
\hline 1 & 85 & female & 11 \\
2 & 67 & male & 20 \\
3 & 88 & male & 20 \\
4 & 58 & male & 23 \\
5 & 68 & male & 1 \\
6 & 60 & male & 23 \\
7 & 85 & male & 18 \\
8 & 69 & female & 23 \\
9 & 87 & female & 22 \\
10 & 66 & male & 22 \\
11 & 51 & male & 24 \\
12 & 79 & male & 18 \\
13 & 62 & male & 21 \\
14 & 80 & female & 15 \\
15 & 74 & male & 11 \\
16 & 61 & male & 19 \\
17 & 93 & female & 21 \\
18 & 90 & female & 18 \\
19 & 56 & male & 14 \\
20 & 71 & male & 23 \\
\hline
\end{tabular}

PM, time between death and corneal explantation.

Table 2. Analysis of unspiked and spiked ante- and postmortem specimens for $\mathrm{HBV}$ infection

\begin{tabular}{|c|c|c|c|c|}
\hline \multirow{3}{*}{$\begin{array}{l}\text { Subject } \\
\text { No. }\end{array}$} & \multicolumn{2}{|l|}{ HBsAg, S/CO } & \multicolumn{2}{|c|}{ Anti-HBc, S/CO } \\
\hline & no spiking & spiking & no spiking & spiking \\
\hline & $\begin{array}{l}\text { ante-/ } \\
\text { postmortem }\end{array}$ & $\begin{array}{l}\text { ante-/ } \\
\text { postmortem }\end{array}$ & $\begin{array}{l}\text { ante-/ } \\
\text { postmortem }\end{array}$ & $\begin{array}{l}\text { ante-/ } \\
\text { postmortem }\end{array}$ \\
\hline 1 & $0.2 / 0.2$ & $5.4 / 4.2$ & $0.1 / 0.1$ & $3.8 / 3.7$ \\
\hline 2 & $0.2 / 0.2$ & $4.7 / 4.2$ & $0.1 / 0.2$ & $3.6 / 3.9$ \\
\hline 3 & $0.1 / 0.1$ & $5.5 / 4.1$ & $0.1 / 0.1$ & $6.1 / 4.5$ \\
\hline 4 & $0.1 / 0.2$ & $4.6 / 4.8$ & $0.1 / 0.1$ & $4.8 / 3.3$ \\
\hline 5 & $0.2 / 0.2$ & $6.0 / 4.2$ & $0.2 / 0.1$ & $3.1 / 5.9$ \\
\hline 6 & $0.2 / 0.2$ & $3.5 / 3.3$ & $0.1 / 0.1$ & $5.8 / 3.8$ \\
\hline 7 & $0.1 / 0.4$ & $1.0 / 1.0$ & $11.1 / 10.5$ & $4.7 / 4.5$ \\
\hline 8 & $0.2 / 0.8$ & $0.7 / 1.4$ & $10.4 / 10.0$ & $3.3 / 3.6$ \\
\hline 9 & $0.2 / 0.2$ & $4.0 / 3.7$ & $0.1 / 0.1$ & $4.4 / 3.9$ \\
\hline 10 & $0.2 / 0.2$ & $3.6 / 3.2$ & $0.1 / 0.1$ & $2.2 / 3.5$ \\
\hline 11 & $0.2 / 0.1$ & $2.3 / 2.2$ & $0.1 / 0.1$ & $2.6 / 3.6$ \\
\hline 12 & $0.1 / 0.1$ & $2.4 / 2.2$ & $0.1 / 0.1$ & $2.2 / 1.0$ \\
\hline 13 & $0.1 / 0.1$ & $2.2 / 2.7$ & $0.1 / 0.1$ & $5.2 / 4.1$ \\
\hline 14 & $0.2 / 0.1$ & $0.9 / 1.1$ & $9.6 / 9.8$ & $3.7 / 4.2$ \\
\hline 15 & $0.1 / 0.3$ & $3.8 / 3.3$ & $0.8 / 0.7$ & $0.9 / 0.7$ \\
\hline 16 & $0.1 / 0.1$ & $1.8 / 1.9$ & $0.1 / 0.1$ & $2.8 / 3.2$ \\
\hline 17 & $0.2 / 0.4$ & $2.9 / 2.3$ & $0.1 / 0.2$ & $3.3 / 3.1$ \\
\hline 18 & $0.2 / 0.2$ & $4.3 / 4.0$ & $0.1 / 0.1$ & $4.7 / 4.0$ \\
\hline 19 & $0.1 / 0.2$ & $3.9 / 3.2$ & $0.1 / 0.1$ & $4.1 / 4.3$ \\
\hline 20 & $0.1 / 0.2$ & $2.9 / 2.5$ & $0.1 / 0.1$ & $5.0 / 4.8$ \\
\hline
\end{tabular}

HBsAg cutoff: $\geq 1.0$. Anti-HBc cutoff: $\geq 1.0$. HBV, hepatitis B virus; $\mathrm{HBsAg}$, hepatitis $\mathrm{B}$ surface antigen; anti- $\mathrm{HBc}$, hepatitis $\mathrm{B}$ core antibody; S/CO, sample/cutoff. was used for detection of inhibition. All assays were carried out according to the manufacturer's instructions. Cutoffs defined by the manufacturer were used to define the negativity and positivity of each sample. Test results from antemortem blood samples were defined as the reference for postmortem blood testing.

\section{Results}

\section{Donor Characteristics}

Overall, 6 female and 14 male donors were included (Table 1). The median age of the cornea donors was 73 years (range 51-93). Related and paired antemortem serum samples were collected up to $72 \mathrm{~h}$ prior to death. Postmortem blood samples were obtained between 1 and $24 \mathrm{~h}$ after death (median $18 \mathrm{~h}$ ).

\section{Ante- and Postmortem Analysis of $\mathrm{HBV}$}

The results for the hepatitis $B$ markers are summarized in Table 2. S/CO ratios $\geq 1$ for $\mathrm{HBsAg}$ and anti-HBc were termed positive. In all donors, the unspiked anteand postmortem samples revealed similar S/CO ratios for HBsAg with negative test results. Thus, no false-positive results were revealed for the cadaveric samples. This finding was similar to that for the HBsAg-spiked samples, except for donors 7, 8, and 14, which showed S/CO values around the cutoff point. A chart review of these donors revealed a positive medical history of a previous HBV infection, and HBV DNA was not detectable in any of the 3 donors by PCR. The anti-HBs titers were very high at $>1,000 \mathrm{IU} / \mathrm{L}$ in each donor, whereas the results for HBsAg showed very low levels - presumably due to resulted anti-HBs binding - in the spiked samples. The ante- and postmortem samples not spiked with anti-HBc were negative, except for patients 7, 8, and 14. Anti-HBc was positive for these patients, and the $\mathrm{S} / \mathrm{CO}$ values were similar for each of these patients in the ante- and postmortem samples, revealing the high stability of anti-HBc in cadaveric samples. Both serologic markers (HBsAg and anti-HBc) of HBV infection did not show any significant differences between paired ante- and postmortem samples.

\section{Ante- and Postmortem Analysis of HCV}

The results of anti-HCV testing and detection of $\mathrm{HCV}$ RNA are shown in Table 3. Anti-HCV was positive at an $\mathrm{S} / \mathrm{CO}$ ratio of $\geq 1.0$. The lower limit of quantification for HCV RNA was $15 \mathrm{IU} / \mathrm{mL}$. All unspiked samples were negative for anti-HCV in the immunoassay, and negative for HCV RNA by PCR, showing similar results among all paired specimens of cornea donors. No false-positive results were found by evaluation of the cadaveric samples. The ante- and postmortem samples spiked with anti$\mathrm{HCV}$ reference serum were positive close to the cutoff 
Table 3. Analysis of unspiked and spiked ante- and postmortem specimens for HCV infection

\begin{tabular}{|c|c|c|c|c|}
\hline \multirow{3}{*}{$\begin{array}{l}\text { Subject } \\
\text { No. }\end{array}$} & \multicolumn{2}{|c|}{ Anti-HCV, S/CO } & \multicolumn{2}{|c|}{ HCV RNA, IU/mL } \\
\hline & no spiking & spiking & no spiking & spiking \\
\hline & $\begin{array}{l}\text { ante-/ } \\
\text { postmortem }\end{array}$ & $\begin{array}{l}\text { ante-/ } \\
\text { postmortem }\end{array}$ & $\begin{array}{l}\text { ante-/ } \\
\text { postmortem }\end{array}$ & $\begin{array}{l}\text { ante-I } \\
\text { postmortem }\end{array}$ \\
\hline 1 & $0.1 / 0.0$ & $2.7 / 2.8$ & $0 / 0$ & $19 / 17$ \\
\hline 2 & $0.1 / 0.1$ & $2.3 / 2.2$ & $0 / 0$ & $24 / 25$ \\
\hline 3 & $0.0 / 0.0$ & $2.9 / 2.3$ & $0 / 0$ & $29 / 37$ \\
\hline 4 & $0.0 / 0.0$ & $2.6 / 2.6$ & $0 / 0$ & $16 / 32$ \\
\hline 5 & $0.1 / 0.1$ & $2.7 / 2.6$ & $0 / 0$ & $34 / 45$ \\
\hline 6 & $0.1 / 0.1$ & $3.0 / 2.8$ & $0 / 0$ & $19 / 30$ \\
\hline 7 & $0.1 / 0.1$ & $2.3 / 2.7$ & $0 / 0$ & $32 / 36$ \\
\hline 8 & $0.1 / 0.1$ & $2.4 / 2.0$ & $0 / 0$ & $35 / 29$ \\
\hline 9 & $0.1 / 0.1$ & $2.6 / 3.5$ & $0 / 0$ & $20 / 27$ \\
\hline 10 & $0.0 / 0.0$ & $3.2 / 3.0$ & $0 / 0$ & $30 / 49$ \\
\hline 11 & $0.1 / 0.0$ & $3.3 / 3.1$ & $0 / 0$ & $23 / 18$ \\
\hline 12 & $0.1 / 0.1$ & $3.4 / 3.4$ & $0 / 0$ & $23 / 27$ \\
\hline 13 & $0.1 / 0.1$ & $4.1 / 5.0$ & $0 / 0$ & $35 / 28$ \\
\hline 14 & $0.1 / 0.0$ & $3.7 / 4.5$ & $0 / 0$ & $19 / 26$ \\
\hline 15 & $0.1 / 0.2$ & $4.9 / 5.1$ & $0 / 0$ & $30 / 32$ \\
\hline 16 & $0.0 / 0.0$ & $4.1 / 4.1$ & $0 / 0$ & $33 / 29$ \\
\hline 17 & $0.1 / 0.1$ & $3.1 / 3.2$ & $0 / 0$ & $52 / 42$ \\
\hline 18 & $0.1 / 0.1$ & $2.2 / 2.4$ & $0 / 0$ & $33 / 17$ \\
\hline 19 & $0.1 / 0.1$ & $3.4 / 3.2$ & $0 / 0$ & $36 / 18$ \\
\hline 20 & $0.1 / 0.1$ & $4.0 / 4.1$ & $0 / 0$ & $17 / 28$ \\
\hline
\end{tabular}

Anti-HCV cutoff: $\geq 1.0$. HCV PCR lower limit of detection: 15 $\mathrm{IU} / \mathrm{mL}$. HCV, hepatitis $\mathrm{C}$ virus; $\mathrm{S} / \mathrm{CO}$, sample/cutoff.
Table 4. Analysis of unspiked and spiked ante- and postmortem specimens for HIV infection

\begin{tabular}{|c|c|c|c|c|}
\hline \multirow{3}{*}{$\begin{array}{l}\text { Subject } \\
\text { No. }\end{array}$} & \multicolumn{2}{|c|}{ Anti-HIV/p24 Ag, S/CO } & \multicolumn{2}{|c|}{ HIV p24 Ag, S/CO } \\
\hline & no spiking & spiking & no spiking & spiking \\
\hline & $\begin{array}{l}\text { ante-/ } \\
\text { postmortem }\end{array}$ & $\begin{array}{l}\text { ante-/ } \\
\text { postmortem }\end{array}$ & $\begin{array}{l}\text { ante-/ } \\
\text { postmortem }\end{array}$ & $\begin{array}{l}\text { ante-I } \\
\text { postmortem }\end{array}$ \\
\hline 1 & $0.2 / 0.1$ & $2.6 / 2.9$ & $0.2 / 0.1$ & $2.6 / 2.7$ \\
\hline 2 & $0.1 / 0.1$ & $2.7 / 3.2$ & $0.1 / 0.1$ & $2.4 / 2.8$ \\
\hline 3 & $0.1 / 1.4$ & $2.1 / 6.3$ & $0.1 / 1.4$ & $2.1 / 1.8$ \\
\hline 4 & $0.0 / 0.0$ & $3.2 / 2.8$ & $0.1 / 0.1$ & $2.3 / 2.5$ \\
\hline 5 & $0.1 / 0.2$ & $2.5 / 3.9$ & $0.1 / 0.2$ & $2.3 / 2.2$ \\
\hline 6 & $0.1 / 0.3$ & $3.8 / 2.8$ & $0.1 / 0.1$ & $2.0 / 3.8$ \\
\hline 7 & $0.1 / 0.2$ & $2.5 / 2.5$ & $0.1 / 0.3$ & $1.8 / 1.6$ \\
\hline 8 & $0.1 / 0.1$ & $2.7 / 1.5$ & $0.1 / 0.2$ & $1.5 / 1.6$ \\
\hline 9 & $0.1 / 0.1$ & $2.9 / 2.8$ & $0.1 / 0.1$ & $1.3 / 1.4$ \\
\hline 10 & $0.1 / 0.3$ & $2.3 / 2.6$ & $0.1 / 0.1$ & $1.6 / 1.7$ \\
\hline 11 & $0.1 / 0.1$ & $2.5 / 3.0$ & $0.1 / 0.3$ & $1.4 / 1.9$ \\
\hline 12 & $0.2 / 0.2$ & $3.2 / 3.5$ & $0.1 / 0.1$ & $1.6 / 1.3$ \\
\hline 13 & $0.1 / 0.1$ & $3.2 / 3.1$ & $0.2 / 0.2$ & $1.2 / 1.5$ \\
\hline 14 & $0.1 / 0.1$ & $3.4 / 3.6$ & $0.1 / 0.1$ & $1.5 / 1.9$ \\
\hline 15 & $0.2 / 0.1$ & $2.7 / 3.1$ & $0.2 / 0.1$ & $1.7 / 1.7$ \\
\hline 16 & $0.1 / 0.1$ & $1.7 / 2.0$ & $0.1 / 0.1$ & $1.5 / 1.6$ \\
\hline 17 & $0.1 / 0.2$ & $2.6 / 2.6$ & $0.1 / 0.2$ & $1.8 / 1.3$ \\
\hline 18 & $0.1 / 0.2$ & $3.0 / 3.4$ & $0.1 / 0.1$ & $2.0 / 1.4$ \\
\hline 19 & $0.1 / 0.1$ & $3.1 / 4.4$ & $0.1 / 0.1$ & $2.2 / 2.0$ \\
\hline 20 & $0.1 / 0.3$ & $3.0 / 3.5$ & $0.1 / 0.1$ & $1.9 / 2.6$ \\
\hline
\end{tabular}

Anti-HIV/p24 Ag cutoff: $\geq 1.0$. HIV p24 Ag cutoff: $\geq 1.0$. HIV, human immunodeficiency virus; $\mathrm{S} / \mathrm{CO}$, sample/cutoff. ratio without any significant differences. In addition, the ante- and postmortem blood samples spiked with $\mathrm{HCV}$ RNA standard showed similar positive results near to the lower limit of quantification, indicating a high stability of viral RNA even in cadaveric blood. No false-negative results were detected in the cadaveric samples spiked with anti-HCV or HCV RNA. An internal control was always positive for all analyzed samples, indicating a valid assay and no inhibition of the PCR due to inhibitory factors in cadaveric blood.

\section{Ante- and Postmortem Analysis of HIV}

The anti-HIV and HIV p24 antigen assays were defined as positive when the $\mathrm{S} / \mathrm{CO}$ ratios were $\geq 1.0$. All anti-HIV- or HIV p24 antigen-spiked samples were positive with S/CO ratios close to the cutoff point; thus, no falsenegative results were detected (Table 4). Donor 3 showed low reactivity for anti-HIV-1 and HIV-1 p24 Ag in the unspiked postmortem samples. PCR targeting HIV RNA was performed on the ante- and postmortem samples of this donor; HIV RNA was not detected, thereby ruling out any previous HIV infection.

All unspiked negative samples were confirmed to be negative for HIV, with the exception of 1 donor who demonstrated a weak signal for anti-HIV or HIV p24 antigen. The spiked samples were positive in regard to all paired ante- and postmortem samples. False-negative results were not observed. In the postmortem blood samples, no significant differences could be detected in regard to donor age, donor sex, or collection time.

\section{Discussion}

Retrieval of tissue from deceased donors is associated with unique challenges, particularly in situations where only cadaveric blood samples are available for testing of markers of blood-borne infectious diseases. In general, human blood is supposed to be modified after death by different factors such as bacterial growth, hemolysis, and autolysis. Finally, modification of the infectious disease markers such as antigens, antibodies, RNA, and DNA might cause false-positive or false-negative test results. Therefore, federal authorities like the PEI, responsible for the preparation, storage, and distribution of donor tissue, demand validation of test systems routinely used for serologic and molecular (NAT) analysis of postmortem blood samples. Currently, most CE-labeled test equipment for infectious 
serology testing is not validated for postmortem samples. For this reason, there is an instant need for validation studies demonstrating the suitability and liability of commercially available assays for postmortem blood analysis.

In the present study, we evaluated the performance of various Abbott test systems on related and paired anteand postmortem sera spiked with viral infection markers such as HBV, HCV, and HIV as recommended by the PEI. The test results showed that the sensitivity of the individual Abbott test assays is comparable between spiked and unspiked serum samples. No lack in sensitivity or inhibition of the assays was observed when using spiked specimens. No false-negative results were detected for any of the HBV, HCV, and HIV infection markers used in the present study. However, a single postmortem blood sample from a cornea donor with a negative history of previous HIV infection showed weak reactivity for HIV. Kalus et al. [17] tested blood samples from cornea donors spiked with Treponema pallidum-positive sera. They also found false-positive results for Treponema pallidum in 2 unspiked postmortem serum samples. The test results were interpreted as the result of extensive postmortem hemolysis. Although there might be additional factors involved, we assume that slight hemolysis was also responsible for the unspecific HIV reactivity observed in one of our postmortem blood samples. Therefore, in any cadaveric serum sample which appears to be macroscopically abnormal, serologic test results should be interpreted with care [18]. For example, Wilkemeyer et al. [16] described false-positive results for viral markers in postmortem blood samples. Based on their results, delayed centrifugation of the previously harvested blood samples might have been a reason for causing the false-positive test results. The spiked antibodies, viral antigens, and viral RNA were stable and not degraded in the cadaveric blood. A high stability of $\mathrm{HBsAg}$, anti-HBc, and antiHCV samples stored in frozen dried blood spots for up to 200 days with minimal variation was recently reported [19]. In our panel, 3 donors had a medical history of a previous $\mathrm{HBV}$ infection. Anti-HBc and anti-HBs antibodies were detected at the same level in the ante- and postmortem samples of these donors; however, HBV DNA could not be detected. Fornés et al. [20] reported the detection of HBV DNA in cornea donors with the same serologic pattern for hepatitis B. In a study performed by Edler et al. [13], serologic detection of antiviral antibodies and viral antigens was possible for up to $48 \mathrm{~h}$ after death. These results indicate a high stability of antibodies and antigens in the postmortem process. The loss of viral load for HBV, HCV, and HIV in clinical samples stored frozen for 9 years has been reported to range up to $0.35 \log _{10}$ [21] We report for the first time a side-by-side comparison of ante- and postmortem samples from the same cornea donor screened for viral infectivity markers.
Between 1984 and 1985, several cases of HBV infection were reported after penetrating keratoplasty [22]. Therefore, screening procedures for human eye banks were introduced in the USA. Since then, no cornea donor-related transmission of infectious diseases has occurred in corneas obtained from and provided by the Eye Bank Association of America over a period of more than 10 years [23]. In 2004, 2 patients received corneas from a rabiesinfected multiorgan donor. The cornea recipients underwent immediate active and passive postexposure treatment and removal of the corneal buttons. Fortunately, no rabies virus transmission was observed during follow-up [24].

Nonrelated ante- and postmortem clinical samples from cornea donors were analyzed by Baleriola et al. [25] Since data on the antemortem status of the cornea donors were unknown, a rate of possible false-negative results could not be determined. In a study by Heim et al. [15], analysis of paired blood samples from 33 cornea donors resulted in discrepancies in about half of the samples. Sixteen postmortem blood samples were false positive for HBsAg, and 1 case showed false-negative reactivity for anti-HCV. In a study by Kitchen and Newham [26], samples from confirmed positive donors were titrated in screen-negative postmortem samples in parallel with normal pooled negative serum to determine if there were signs of inhibition with the postmortem samples. No statistically significant differences were observed between the diluted samples. According to Meyer et al. [27], the time point of postmortem blood sampling for $\mathrm{HBV}, \mathrm{HCV}$, and HIV testing may be extended to $36 \mathrm{~h}$ or even $48 \mathrm{~h}$, thereby improving the availability of donor tissue.

The prevalence rates of HBV, HCV, and HIV infections are lower among tissue donors than in the general population. However, the estimated probability of undetected viremia at the time of tissue donation is higher among tissue donors than among first-time blood donors. Adding nucleic acid amplification test methods to screening regimes for tissue donors should reduce the risk of disease transmittance among tissue recipients [12, $24,28]$. Introduction of NAT screening procedures for HCV RNA substantially shortens the diagnostic window period. HCV infections may be detected about 20-60 days earlier [29]. In a report by Challine et al. [30], 5 out of 2,119 anti-HCV-seronegative organ donors and 1 out of $631 \mathrm{HCV}$-seronegative tissue donors were HCV RNA positive. Gubbe et al. [31] performed a validation of the detection of nucleic acids in cadaveric samples. The analytic specificity and sensitivity for HBV, HCV, and HIV with an automated NAT system was $100 \%$. Miédougé et al. [14] analyzed postmortem samples of cornea donors for HCV RNA and HIV RNA. In cornea donors with a negative serology for HCV and HIV, RNA of HCV and 
HIV was not found; however, indeterminate molecular results were found for $17.6 \%$ of the samples, and thus were frequently detected in cadaveric samples. In our study, amplification of the internal control ensured that the negative results were valid. Pruss et al. [32] recommend that NATs for HBV, HCV, and HIV should be performed on all tissue donors as an additional measure for viral safety. Although corneal allografts carry the lowest risk of transmitting viral factors owing to corneal physiology and morphology as well as the epidemiology of corneal diseases, NATs for HCV should still be performed.

\section{Conclusion}

Our study showed no differences in the results obtained for HBV, HCV, and HIV markers between ante- and postmortem blood samples. Therefore, we suggest that an identification of antibodies, antigens, and/or RNA markers in samples collected postmortem is possible at levels comparable to those obtained by the screening currently performed on living donors. Accurate detection of these infectious diseases in potential donors is maintained in samples collected within $24 \mathrm{~h}$ of death, provided that the presence of blood-borne agents is being adequately assessed using routine serum screening prior to cornea donation.

\section{Acknowledgements}

The authors like to thank Markus Zorn and Andrea Morath for their valuable support in providing antemortem blood samples from deceased donors. We also wish to gratefully acknowledge the members of the virology diagnostic laboratory for their excellent support. We like to thank Alison Jefferson for critically reading the manuscript.

\section{Statement of Ethics}

The present study was approved by the local Ethics Committee of Heidelberg University (S-293/2012) and was performed in accordance with the Declaration of Helsinki. Informed consent was obtained from the relatives of each cornea donor prior to tissue collection.

\section{Disclosure Statement}

The authors have no competing interests to declare.

\section{References}

1 Zirm EK. Eine erfolgreiche totale Keratoplastik (A successful total keratoplasty). 1906. Refract Corneal Surg. 1989 Jul-Aug;5(4):25861.

2 Ple-Plakon PA, Shtein RM. Trends in corneal transplantation: indications and techniques. Curr Opin Ophthalmol. 2014 Jul;25(4):300-5.

3 European Directorate for the Quality of Medicines \& HealthCare (EDQM). Guide to the quality and safety of tissues and cells for human application. 3rd edition. Strasbourg: EDQM, Council of Europe; 2017. Appendix 16.

4 European Union, Directive 2006/86/EC of 24 October 2006 implementing Directive 2004/23/EC with regards to certain technical requirements for the coding, processing, preservation, storage and distribution of human cells and tissues. Off J Europ Union. 2006; 294:32-50.

5 European Eye Bank Association (EEBA). EEBA Standards, Minimum Medical Standards (MMS). 2nd rev, 01.02.2015. In: Directory of European Eye Bank Association. Available from: www.eeba.eu.

6 European Eye Bank Association (EEBA) EEBA Standards, Technical Guidelines for Ocular Tissue (TGOCT). 7th rev, 01.02.2015. In: Directory of European Eye Bank Association. Available from: www.eeba.eu.
7 Federal Ministry of Justice. Report of the German Government about the Supply with Tissues and Tissue Preparations in Germany (Article 7a GewG) (10.08.2010). Available from: http://www.bmg.bund.de/fileadmin/ redaktion/pdf_misc/Bericht-BReg-Gewebe. pdf.

8 Borderie VM. Donor selection, retrieval and preparation of donor tissue. Donor selection. In: Bredehorn-Mayr T, Duncker GIW, Armitage WJ, editors. Eye banking. Dev Ophthalmol. Basel: Karger; 2009. vol. 43, pp. 2230.

9 Schroeter J, Maier P, Bednarz J, Blüthner K, Quenzel M, Pruss A, et al. Procedural guidelines. Good tissue practice for cornea banks [in German]. Ophthalmologe. 2009 Mar; 106(3):265-74.

10 Eastlund $\mathrm{T}$. Infectious disease transmission through cell, tissue, and organ transplantation: reducing the risk through donor selection. Cell Transplant. 1995 Sep-Oct;4(5):45577.

11 Ison MG, Hager J, Blumberg E, Burdick J, Carney K, Cutler J, et al. Donor-derived disease transmission events in the United States: data reviewed by the OPTN/UNOS Disease Transmission Advisory Committee. Am J Transplant. 2009 Aug;9(8):1929-35.

12 Zou S, Dodd RY, Stramer SL, Strong DM; Tissue Safety Study Group. Probability of viremia with HBV, HCV, HIV, and HTLV among tissue donors in the United States. N Engl J Med. 2004 Aug;351(8):751-9.
13 Edler C, Wulff B, Schröder AS, Wilkemeyer I, Polywka S, Meyer T, et al. A prospective timecourse study on serological testing for human immunodeficiency virus, hepatitis B virus and hepatitis $\mathrm{C}$ virus with blood samples taken up to $48 \mathrm{~h}$ after death. J Med Microbiol. 2011 Jul;60(Pt 7):920-6.

14 Miédougé M, Chatelut M, Mansuy JM, Rostaing L, Malecaze F, Sandres-Sauné K, et al. Screening of blood from potential organ and cornea donors for viruses. J Med Virol. 2002 Apr;66(4):571-5.

15 Heim A, Wagner D, Rothämel T, Hartmann U, Flik J, Verhagen W. Evaluation of serological screening of cadaveric sera for donor selection for cornea transplantation. J Med Virol. 1999 Jul;58(3):291-5.

16 Wilkemeyer I, Pruss A, Kalus U, Schroeter J. Comparative infectious serology testing of pre- and post-mortem blood samples from cornea donors. Cell Tissue Bank. 2012 Aug; 13(3):447-52.

17 Kalus U, Wilkemeyer I, Pruss A, Caspari G. Validation of serological testing for antiTreponema pallidum from postmortem blood on the Siemens BEP-III automatic system. Transfus Med Hemother. 2013 Dec; 40(6):403-8.

18 Challine D, Roudot-Thoraval F, Sabatier P, Dubernet F, Larderie P, Rigot P, et al. Serological viral testing of cadaveric cornea donors. Transplantation. 2006 Sep;82(6):78893. 
19 McAllister G, Shepherd S, Templeton K, Aitken C, Gunson R. Long term stability of HBsAg, anti-HBc and anti-HCV in dried blood spot samples and eluates. J Clin Virol. 2015 Oct; $71: 10-7$.

20 Fornés MG, Jiménez MA, Eisman M, Gómez Villagrán JL, Villalba R. Nucleic acid-amplification testing for hepatitis $\mathrm{B}$ in cornea donors. Cell Tissue Bank. 2016 Jun;17(2):341-4.

21 Baleriola C, Johal H, Jacka B, Chaverot S, Bowden S, Lacey S, et al. Stability of hepatitis $C$ virus, $\mathrm{HIV}$, and hepatitis B virus nucleic acids in plasma samples after long-term storage at $-20^{\circ} \mathrm{C}$ and $-70^{\circ} \mathrm{C}$. J Clin Microbiol. 2011 Sep;49(9):3163-7.

22 Hoft RH, Pflugfelder SC, Forster RK, Ullman S, Polack FM, Schiff ER. Clinical evidence for hepatitis B transmission resulting from corneal transplantation. Cornea. 1997 Mar; 16(2):132-7.

23 Glasser DB. Serologic testing of cornea donors. Cornea. 1998 Mar;17(2):123-8.
24 Vetter JM, Frisch L, Drosten C, Ross RS, Roggendorf M, Wolters B, et al. Survival after transplantation of corneas from a rabies-infected donor. Cornea. 2011 Feb;30(2):241-4.

25 Baleriola C, Johal H, Robertson P, Jacka B, Whybin R, Taylor P, et al. Infectious disease screening of blood specimens collected postmortem provides comparable results to premortem specimens. Cell Tissue Bank. 2012 Jun;13(2):251-8.

26 Kitchen AD, Newham JA. Qualification of serological infectious disease assays for the screening of samples from deceased tissue donors. Cell Tissue Bank. 2011 May;12(2):117-24.

27 Meyer T, Polywka S, Wulff B, Edler C, Schröder AS, Wilkemeyer I, et al. Virus NAT for HIV, HBV and HCV in post-mortal blood specimens over $48 \mathrm{~h}$ after death of infected patients - first results. Transfus Med Hemother. 2012 Dec;39(6):376-80.
28 Roth WK, Weber M, Petersen D, Drosten C, Buhr S, Sireis W, et al. NAT for HBV and anti-HBc testing increase blood safety. Transfusion. 2002 Jul;42(7):869-75.

29 Singer AL, Kucirka LM, Namuyinga R, Hanrahan C, Subramanian AK, Segev DL. The high-risk donor: viral infections in solid organ transplantation. Curr Opin Organ Transplant. 2008 Aug;13(4):400-4.

30 Challine D, Pellegrin B, Bouvier-Alias M, Rigot P, Laperche L, Pawlotsky JM. HIV and hepatitis $\mathrm{C}$ virus RNA in seronegative organ and tissue donors. Lancet. 2004 Oct; 364(9445):1611-2.

31 Gubbe K, Scharnagl Y, Grosch S, Tonn T, Schmidt M, Hourfar KM, et al. Validation of virus NAT for HIV, HCV, HBV and HAV using post-mortal blood samples. Transfus Med Hemother. 2012 Dec;39(6):381-5.

32 Pruss A, Caspari G, Krüger DH, Blümel J, Nübling CM, Gürtler L, et al. Tissue donation and virus safety: more nucleic acid amplification testing is needed. Transpl Infect Dis. 2010 Oct;12(5):375-86 